\title{
PENGEMBANGAN GAME EDUKATIF BERBASIS RPG MAKER XP SEBAGAI MEDIA PEMBELAJARAN AKUNTANSI
}

\author{
Asriyatun \\ Prodi Pendidikan Akuntansi Universitas Negeri Yogyakarta \\ asriyaa.akt@gmail.com \\ Mahendra Adhi Nugroho \\ Jurusan Pendidikan Akuntansi Universitas Negeri Yogyakarta
}

\begin{abstract}
Abstrak
Penelitian ini merupakan penelitian pengembangan berupa game edukatif sebagai media pembelajaran Akuntansi untuk siswa SMK Kelas XI. Penelitian ini bertujuan untuk mengembangkan game edukatif berbasis Role-Playing Game (RPG) Maker XP sebagai media pembelajaran Akuntansi, mengetahui kelayakan game edukatif tersebut sebagai media pembelajaran, dan mengetahui pengaruhnya terhadap peningkatan hasil belajar siswa. Metode penelitian ini adalah Research and Development (R\&D). Tahapan dalam pengembangan game edukatif ini meliputi: tahap identifikasi potensi dan masalah, pengumpulan informasi, desain produk, pengembangan produk, validasi produk, revisi produk, uji coba produk, dan analisis dan revisi produk akhir. Pada tahap validasi, game edukatif ini divalidasi oleh dosen sebagai ahli media dan ahli materi serta guru akuntansi. Game edukatif diujicobakan kepada siswa kelas XI SMK Negeri 1 Godean yang berjumlah 32 siswa. Teknik pengumpulan data dalam penelitian ini melalui angket dan tes. Data yang diperoleh dari angket dianalisis secara deskriptif kualitatif dan kuantitatif, sedangkan data dari hasil tes dianalisis menggunakan Gain-test. Hasil penelitian menunjukkan bahwa tingkat kelayakan game edukatif sebagai media pembelajaran berdasarkan penilaian ahli media diperoleh nilai rata-rata 4,26 yang termasuk dalam kategori Sangat Layak, ahli materi diperoleh nilai rata-rata 4,14 termasuk dalam kategori Layak, guru Akuntansi diperoleh nilai rata-rata 4,77 yang termasuk dalam kategori Sangat Layak, dan penilaian siswa menunjukkan nilai rata-rata 4,43 yang termasuk dalam kategori Sangat Layak. Dengan demikian, game edukatif berbasis Role-Playing Game (RPG) Maker XP ini layak digunakan sebagai media pembelajaran. Berdasarkan analisis peningkatan hasil belajar siswa dari hasil pre-test dan post-test yang diberikan pada saat uji coba, diperoleh nilai gain sebesar 0,55 pada kategori sedang. Dengan demikian, peningkatan hasil belajar siswa dengan menggunakan game edukatif ini tergolong sedang.
\end{abstract}

Kata kunci: Role-Playing Game (RPG) Maker XP, Game Edukatif sebagai media pembelajaran, Akuntansi

\footnotetext{
Abstract

This researchis development researchin the form of educative game as Accounting learning media for SMK students grade XI. Objective of the research is to developRole-Playing Game (RPG) Maker XP -based educative game as Accounting learning media, and find out its effectiveness as well as its influence toward improvement of student learning result. Method or the research is Research and Development $(R \& D)$. Stages in developing the educative game are identifying potential and problem, collecting information, designing product,
} 
developing product, validating product, revising product, trying outproduct, and analyzing and revising final product. The educative game is validated by lecturer, as media and material expert, and Accounting teacher. It is tried out on 32 students of grade XI of SMK Negeri 1 Godean. Data of this research are collected through questionnaire and test. The data collected from the questionnaire are analyzed descriptively qualitatively and quantitatively and the data collected from the test are analyzed by using Gain-test. Result of the research finds out that level or effectiveness of the educative game as Accounting learning media based on media expert assessment is in average 4,26 which is categorized Very Effective, material expert scores 4,14 which is categorized Effective, accounting teacher scores 4,77 which is categorized Very Effective, and students scores 4,43 which is categorized Very Effective. Hence, Role-Playing Game (RPG) Maker XP -based educative game is effective to be utilized as Accounting learning media. Based on student learning result analysis resulted from pre-test and post-test given in the tryout, the gain score is 0,55 on average category. In conclusion, improvement of students learning result through the educative game is categorized Average.

Keywords: Role-Playing Game (RPG) Maker XP, Educative game as learning media, Accounting.

\section{PENDAHULUAN}

Pendidikan tidak dapat lepas dari proses belajar mengajar. Proses belajar mengajar terjadi karena adanya interaksi antara seseorang dengan lingkungannya yang terdiri dari pendidik, peserta didik, bahan pelajaran, sumber belajar dan media pembelajaran, sarana dan prasarana, serta pihak manajemen lembaga pendidikan tersebut. Dunia pendidikan selalu berupaya untuk mencetak generasi penerus bangsa yang lebih siap untuk menghadapi tantangan dalam kehidupan yang senyatanya. Salah satu komponen utama yang mencetak generasi penerus bangsa yang berkualitas adalah seorang pendidik, baik di sekolah maupun di lembaga pendidikan non formal lainnya. Dunia pendidikan selalu berupaya untuk mencetak generasi penerus bangsa yang lebih siap untuk menghadapi tantangan dalam kehidupan yang senyatanya yaitu bersaing dengan masyarakat lainnya. Pendidik sangat berperan dalam hal tersebut karena pendidik terlibat langsung dalam interaksi yang terjadi dalam proses belajar mengajar. Oleh karena itu, seorang pendidik harus mengetahui bagaimana cara dan dengan apa ia menyampaikan informasi.

Perkembangan ilmu pengetahuan dan teknologi semakin mendorong upayaupaya pembaharuan dalam pemanfaatan hasil teknologi untuk diterapkan dalam proses belajar. Salah satunya adalah dengan memanfaatkan teknologi sebagai media pembelajaran yang dapat digunakan di sekolah. Dina Indriana (2011: 13) 
mengutarakan bahwa media adalah saluran komunikasi. Kata media berasal dari bahasa Latin yang merupakan bentuk jamak dari kata medium. Secara harfiah, media berarti perantara yaitu perantara antara sumber pesan dengan penerima pesan. Dina Indriana (2011: 130) menyebutkan beberapa hal yang termasuk dalam media adalah film, televisi, diagram, media cetak, komputer, instruktur, dan sebagainya. Apabila media itu membawa pesan-pesan atau informasi yang bertujuan instruksional atau mengandung maksud pengajaran maka media itu disebut media pembelajaran. Menurut Kemp and Dayton (1985) dalam Wina Sanjaya (2012: 210), media memiliki kontribusi yang sangat penting terhadap proses pembelajaran, yaitu penyampaian pesan pembelajaran dapat lebih terstandar, pembelajaran dapat lebih menarik, proses pembelajaran dapat berlangsung kapan dan dimana pun diperlukan terutama jika media dirancang untuk penggunaan secara individu, serta sikap positif siswa terhadap materi pembelajaran serta pembelajaran dapat ditingkatkan.

Salah satu standar kompetensi yang diajarkan di SMK Negeri 1 Godean pada Kompetensi Keahlian Akuntansi khususnya kelas XI adalah Menyiapkan Surat Pemberitahuan (SPT) Pajak. Perpajakan yang diajarkan di SMK merupakan pelajaran yang lebih banyak menekankan pada teori dan latihan soal untuk menghitung berapa pajak yang dibayarkan. Hal tersebut bertolak belakang dengan keadaan siswa yang mengalami kesulitan belajar dalam memahami teori.Berdasarkan observasi di Kelas XI AK 1 SMK Negeri 1 Godean pada mata pelajaran Perpajakan, diperoleh hasil antara lain media pembelajaran yang digunakan masih kurang variatif. Selain itu, proses pembelajaran juga masih terpusat pada guru (teacher centered) dan pada mata pelajaran perpajakan masih banyak siswa Kelas XI AK 1 belum tuntas KKM yaitu sekitar 56,25\% atau 18 siswa dari 32 siswa di kelas belum mencapai KKM. Tentu saja hal tersebut bukan semata-mata kesalahan guru dalam mengajar, masih banyak faktor lain yang mempengaruhi keberhasilan siswa dalam belajar.

$$
\text { Berdasarkan permasalahan }
$$
tersebut, dapat dihadirkan sebuah media pembelajaran yang interaktif dan inovatif dapat dibuat dengan memanfaatkan teknologi informasi dan komunikasi yang sudah berkembang dengan pesat di masyarakat, salah satunya dengan menggunakan komputer. Menurut Wina Sanjaya (2012: 219) ada beberapa bentuk penggunaan komputer sebagai media yang dapat digunakan dalam pembelajaran, 
yaitu: penggunaan multimedia presentasi, CD Multimedia Interaktif yang terdiri dari model drill, tutorial, simulasi, dan game, serta pemanfaatan internet. Multimedia interaktif berupa game sebenarnya sangat berguna dalam kegiatan belajar mengajar, namun belum banyak yang mengembangkan game sebagai media pembelajaran khususnya untuk akuntansi.

Salah satu genre game yang ada yaitu Role-Playing Game (RPG). Samuel Henry (2010: 129) menyatakan bahwa RPG merupakan game yang pemainnya akan berperan menjadi sebuah karakter. Selain itu, berdasarkan hasil survei yang dilakukan oleh salah satu studio game di Indonesia yaitu Agate studio pada tahun 2012 (Agate: 2012), genre RPG ini merupakan game terfavorit yang dipilih untuk dimainkan oleh para gamer. Berdasarkan kondisi seperti ini, para pendidik atau masyarakat umum lainnya dapat mengambil peluang untuk mengembangkan RPG sebagai game edukatif yang berisikan materi pelajaran yang bisa digunakan sebagai media di sekolah.

Role-Playing Game disingkat RPG adalah sebuah permainan yang para pemainnya memainkan peran tokoh-tokoh khayalan dan berkolaborasi untuk merajut sebuah cerita bersama. SEAMOLEC (2010: 3) menjelaskan bahwa Role-Playing
Game Maker atau RPG Maker merupakan sebuah software yang digunakan untuk membuat permainan dengan jenis RPG. Software ini dapat digunakan oleh orang awam yang tidak mengerti bahasa pemrograman sekalipun karena dalam software ini sudah tersedia sumber daya seperti gambar, suara, animasi, dan sebagainya. Dalam program RPG Maker telah tersedia berbagai fitur mulai dari desain alam atau latar belakang cerita petualangan dalam game maupun berbagai karakter, perangkat musik, gambar, juga dialog. Melalui latihan, masing-masing individu yang telah mengenal komputer akan mampu merancang game sesuai tujuan dan orientasi masing-masing dari penciptaaan game tersebut.

Ada tiga tahapan dalam proses pembuatan game ini yaitu:

\section{a. Mapping}

Map adalah lokasi dimana karakter dari game dapat bergerak atau bisa disebut sebagai latar dari game, untuk itu map yang dibuat harus sesuai dengan alur cerita dalam game. Mapping adalah proses pembuatan map. Proses mapping membutuhkan imajinasi yang tinggi dari pembuat, agar map yang dibuat dapat terlihat nyata dan tidak menyimpang dari alur cerita.

\section{b. Database Using}


Database using adalah proses pengaturan parameter-parameter untuk objek yang ada dalam game. Objek ini antara lain: tokoh, senjata, animasi, dan suara.

c. Eventing

Eventing adalah proses pemberian perilaku pada objek yang ada di dalam game. Perilaku objek yang diatur dalam proses ini antara lain: dialog antar tokoh, binatang yang berjalan, backsound, perpindahan tokoh ke map lain, dan pertempuran.

\section{METODE}

\section{Jenis Penelitian}

Penelitian ini tergolong dalam penelitian dan pengembangan atau research and development $(\mathrm{R} \& \mathrm{D})$.

\section{Subjek Penelitian}

Subjek penelitian (subjek uji coba produk) adalah siswa kelas XI Akuntansi 1 SMKN 1 Godean.

\section{Langkah-Langkah Pengembangan}

Prosedur yang digunakan dalam pengembangan produk ini merupakan adaptasi dari langkah-langkah penelitian dan pengembangan oleh Sugiyono (2012: 409) yaitu: 1) identifikasi potensi dan masalah; 2) pengumpulan informasi; 3) desain produk; 4) pengembangan produk;
5) validasi produk; 6) revisi produk; 7) uji coba produk; 8) analisis dan revisi produk akhir.

\section{Data, Instrumen dan Teknik Pengumpulan}

Data pada penelitian ini adalah data kuantitatif dan kualitatif. Data tersebut diperoleh dari angket penilaian kelayakan media dan hasil pre-test dan post-test.

\section{Teknik Analisis Data}

Data kualitatif berupa saran/masukan yang diberikan oleh dosen ahli materi, media, guru, dan siswa dianalisis secara deskriptif. Data tersebut digunakan sebagai dasar peneliti dalam merevisi produk.

Data kuantitatif diperoleh dari angket penilaian kelayakan produk yang diberikan kepada dosen ahli materi, media, guru, dan siswa. Data kelayakan game tersebut berupa data kualitatif. Untuk mendapatkan penilaian kelayakan game, maka data kualitatif tersebut dikonversi menjadi data kuantitatif dengan cara memberikan skor. Skor angket menggunakan skala Likert dengan skala 15. Kemudian data yang terkumpul dianalisis dengan cara menghitung ratarata skor yang diperoleh. Rata-rata hasil penilaian tersebut merupakan data kuantitatif, kemudian dikonversi kembali 
menjadi data kualitatif menjadi kategori kelayakan game sehingga dapat diambil kesimpulan mengenai kelayakan game sebagai media pembelajaran berdasarkan pedoman konversi ideal yang dijabarkan pada tabel berikut ini.

Tabel 1. Pedoman Konversi Skor

\begin{tabular}{cll}
\hline No & \multicolumn{1}{c}{ Rumus } & Kategori \\
\hline 1 & $\mathrm{X}>\bar{X}_{l}+1,8 \mathrm{SB}_{\mathrm{i}}$ & Sangat \\
& & Layak \\
2 & $X_{i}+0,6 \mathrm{SB}_{\mathrm{i}}<\mathrm{X} \leq X_{i}+1,8 \mathrm{SB}_{\mathrm{i}}$ & Layak \\
3 & $X_{i}-0,6 \mathrm{SB}_{\mathrm{i}}<\mathrm{X} \leq X_{i}+0,6 \mathrm{SB}_{\mathrm{i}}$ & Cukup \\
& & Layak \\
4 & $X_{i}-1,8 \mathrm{SB}_{\mathrm{i}}<\mathrm{X} \leq X_{i}-0,6 \mathrm{SB}_{\mathrm{i}}$ & Kurang \\
& & Layak \\
5 & $\mathrm{X} \leq X_{i}-1,8 \mathrm{SB}_{\mathrm{i}}$ & Sangat \\
& & Kurang \\
& & Layak \\
\hline
\end{tabular}

Sumber: Sukardjo (2012: 96)

Sedangkan untuk data peningkatan hasil belajar dari hasil pre-test dan posttestakan dianalisis dengan menggunakan gain-test. Teknik analisis data gain-test adalah dengan menghitung nilai gain $(\mathrm{g})$, yaitu:

$$
g=\frac{\text { skorposttest }- \text { skorpretest }}{\text { skormaksimum - skorpretest }}
$$

Hake (2012: 1)

\section{HASIL DAN PEMBAHASAN}

Pengembangan Game Edukatif Berbasis Role-PlayingGame Maker XP

Prosedur yang digunakan dalam pengembangan produk ini merupakan adaptasi dari langkah-langkah penelitian dan pengembangan oleh Sugiyono (2011: 298) yaitu:

a. Tahap Identifikasi Potensi dan Masalah

Penelitian ini berangkat dari adanya potensi yang dimiliki SMK Negeri 1 Godean. Sekolah memiliki sarana dan prasarana yang cukup memadai antara lain memiliki laboratorium komputer sebanyak 3 buah, beberapa ruang kelas yang memiliki LCD, dll. Selain itu, siswa juga suka bermain game. Potensi yang dimiliki memang cukup baik namun media pembelajaran yang digunakan masih belum bervariasi.

b. Tahap Pengumpulan Informasi.

Informasi yang dikumpulkan berupa informasi mengenai kompetensi atau materi yang disampaikan dalam game dan perangkat keras dan perangkat lunak.

c. Tahap Desain Produk

Menyusun kerangka materi, menyusun alur cerita menyusun flowchart, menyusun Story board

d. Tahap Pengembangan Produk 
1) Pembuatan halaman awal. Proses pembuatan game diawali dari pembuatan halaman awal atau cover game yang muncul pada saat game dibuka. Halaman awal terdiri atas halaman judul dan halaman tentang.

2) Pembuatan Map (Mapping). Setelah halaman awal jadi, kemudian peneliti mulai membuat game dengan menggunakan software RPG Maker XP. Game edukatif ini dibuat dengan 3 level permainan, dimana antara level satu dengan level lainnya memiliki perbedaan baik dari materi maupun soal yang dikerjakan. Langkah pertama yang dilakukan pada tahap pembuatan media yaitu membuat map. Map merupakan objek/lokasi/tempat-tempat yang dilalui oleh player.

3) Coding/Eventing.

Coding dilakukan agar objek yang terdapat pada map dapat berfungsi. Istilah dalam RPG Maker XP tahap ini disebut tahap eventing. Eventing merupakan proses untuk memasukkan kejadian-kejadian yang terjadi pada game ini.

4) Testing. Testing dilakukan setelah proses coding atau eventing selesai. Testing dilakukan untuk mengetahui apakah event dapat dijalankan atau tidak. Testing diawali dengan melakukan playtestgame, menu ini terdapat dalam aplikasi RPG Maker XP.

5) Pemaketan. File yang dihasilkan dari tahap testing merupakan file mentah. File mentah hanya dapat dijalankan pada komputer yang telah ter-install software RPG Maker XP. Oleh karena itu, filegame mentah harus dibuat menjadi file independent agar game bisa dijalankan pada komputer yang tidak terinstall software RPG Maker XP.

e. Tahap Validasi Produk. Validasi Ahli Media yang ditinjau dari aspek rekayasa perangkat lunak dan komunikasi visual. Validasi Ahli Materi yang ditinjau dari aspek materi, soal, kebahasaan dan keterlaksanaan. Validasi guru Akuntansi yang mengajar di SMKN 1 Godean untuk mengetahui apakah media bisa diterapkan di lapangan atau tidak.

f. Tahap Revisi Produk. Revisi produk dilakukan setelah validasi dari beberapa ahli. Komentar dan saran yang diberikan ahli menjadi dasar untuk merevisi produk agar menjadi lebih baik lagi sebelum media diujicobakan ke siswa. 
g. Tahap Uji Coba Produk. Uji coba produk dilaksanakan setelah game selesai direvisi.

h. Tahap Analisis dan Revisi Produk Akhir. Berdasarkan saran yang diberikan, peneliti merevisi game untuk menjadi produk akhir sebuah game edukatif perpajakan.

\section{Kelayakan Produk Game Edukatif} Berbasis Role-Playing Game Maker XP

a. Ahli Media

Ahli Media memberikan penilaian terhadap game eduktif ini dengan mengisi angket Lembar Penilaian Media. Penilaian tersebut digunakan untuk menentukan kelayakan game sebagai media pembelajaran. Kelayakan Produk berdasarkan Validasi dari Ahli Media, yaitu:

Tabel 2. Hasil Validasi Ahli Media

$\begin{array}{ccccc} & \text { Aspek } & \text { Jumlah } & \text { Rata- } & \\ \text { No } & \text { Penilaian } & \text { Nilai } & \text { rata } & \text { Kategori } \\ & & & \text { Nilai } & \end{array}$

$\begin{array}{lllll}1 & \text { Rekayasa } & 112 & 4,31 & \text { Sangat } \\ & \text { Perangkat } & & & \text { Layak } \\ & \text { Lunak } & & & \end{array}$

2 Komunikasi $101 \quad 4,21 \quad$ Sangat

Visual

Layak

Total

213
Secara keseluruhan, rata-rata penilaian oleh ahli media diperoleh nilai 4,26. Hasil penilaian tersebut masuk dalam rentang nilai $X>4,2$ dengan kategori Sangat Layak. Sehingga kelayakan game edukatif ini termasuk ke dalam kategori Sangat Layak.

b. Kelayakan Produk berdasarkan Ahli Materi

Ahli Materi memberikan penilaian terhadap game edukatif ini dengan mengisi angket Lembar Penilaian Media untuk Ahli Materi. Penilaian tersebut digunakan untuk menentukan kelayakan game sebagai media pembelajaran dilihat dari materi yang disampaikan.

Tabel 3. Hasil Validasi Ahli Materi

\begin{tabular}{|c|c|c|c|c|}
\hline No. & $\begin{array}{c}\text { Aspek } \\
\text { Penilaian }\end{array}$ & $\begin{array}{c}\text { Jumlah } \\
\text { Nilai }\end{array}$ & $\begin{array}{l}\text { Rata- } \\
\text { rata } \\
\text { nilai }\end{array}$ & Kategori \\
\hline 1 & Materi & 38 & 4,22 & $\begin{array}{l}\text { Sangat } \\
\text { Layak }\end{array}$ \\
\hline 2 & Soal & 24 & 4 & Layak \\
\hline 3 & $\begin{array}{l}\text { Kebaha- } \\
\text { saan }\end{array}$ & 8 & 4 & Layak \\
\hline 4 & $\begin{array}{l}\text { Keterlak- } \\
\text { sanaan }\end{array}$ & 13 & 4,33 & $\begin{array}{l}\text { Sangat } \\
\text { Layak }\end{array}$ \\
\hline & Total & 83 & 4,14 & Layak \\
\hline
\end{tabular}


Secara keseluruhan, rata-rata penilaian oleh ahli materi diperoleh nilai 4,14. Hasil penilaian tersebut masuk dalam rentang nilai $3,4<\mathrm{X} \leq$ 4,2 dengan kategori Layak. Sehingga tingkat kelayakan game edukatif berdasarkan validasi ahli materi masuk ke dalam kategori Layak.

c. Kelayakan Produk berdasarkan penilaian guru

Guru sebagai pelaksana pendidikan di lapangan juga memberikanpenilaian terhadap game edukatif ini dengan mengisi angket Lembar Penilaian Media. Validator dari guru adalah guru produktif akuntansi yang mengajar Perpajakan di SMK Negeri 1 Godean.

Secara keseluruhan, rata-rata penilaian oleh guru diperoleh nilai 4,77. Hasil penilaian tersebut masuk dalam rentang nilai $X>4,2$ dengan kategori Sangat Layak. Sehingga tingkat kelayakan game edukatif ini termasuk ke dalam kategori Sangat Layak.
Tabel 4. Hasil Validasi Guru

\begin{tabular}{|c|c|c|c|c|}
\hline No & $\begin{array}{c}\text { Aspek } \\
\text { Penilaian }\end{array}$ & $\begin{array}{l}\text { Jml. } \\
\text { Nilai }\end{array}$ & $\begin{array}{l}\text { Rata- } \\
\text { rata } \\
\text { nilai }\end{array}$ & Kategori \\
\hline 1 & $\begin{array}{l}\text { Rekayasa } \\
\text { Perangkat } \\
\text { Lunak }\end{array}$ & 29 & 4,83 & $\begin{array}{l}\text { Sangat } \\
\text { Layak }\end{array}$ \\
\hline 2 & $\begin{array}{l}\text { Desain } \\
\text { Pembela- } \\
\text { jaran }\end{array}$ & 66 & 4,71 & $\begin{array}{l}\text { Sangat } \\
\text { Layak }\end{array}$ \\
\hline 3 & $\begin{array}{l}\text { Komuni- } \\
\text { kasi } \\
\text { Visual }\end{array}$ & 38 & 4,75 & $\begin{array}{l}\text { Sangat } \\
\text { Layak }\end{array}$ \\
\hline & Total & 133 & 4,77 & $\begin{array}{l}\text { Sangat } \\
\text { Layak }\end{array}$ \\
\hline
\end{tabular}

d. Kelayakan Produk berdasarkan penilaian siswa

Siswa sebagai subjek uji coba juga memberikan penilaian terhadap game edukatif ini dengan mengisi angket Lembar Penilaian Media. Penilaian tersebut digunakan untuk menentukan kelayakan game sebagai media pembelajaran yang diterapkan di sekolah. Hasil penilaian dari siswa dapat dilihat pada tabel 5 berikut ini.

Secara keseluruhan, rata-rata penilaian oleh siswa diperoleh nilai 4,43. Hasil penilaian siswa tersebut masuk dalam rentang nilai $X>4,2$ dengan kategori Sangat Layak 
sehingga tingkat kelayakan game edukatif berdasarkan penilaian siswa tergolong Sangat Layak.

Tabel 5. Hasil Penilaian Siswa

\begin{tabular}{ccccc}
\hline No & \multicolumn{1}{c}{$\begin{array}{c}\text { Aspek } \\
\text { Penilaian }\end{array}$} & $\begin{array}{c}\text { Jumlah } \\
\text { Nilai }\end{array}$ & $\begin{array}{c}\text { Rata- } \\
\text { rata } \\
\text { nilai }\end{array}$ & Kategori \\
\hline 1 & $\begin{array}{l}\text { Rekayasa } \\
\text { Perangkat }\end{array}$ & 729 & 4,56 & Layak \\
& $\begin{array}{l}\text { Lunak } \\
2\end{array}$ & & & \\
Desain & 1278 & 4,44 & Sangat \\
& $\begin{array}{l}\text { Pembela- } \\
\text { jaran }\end{array}$ & & & Layak \\
Komuni- & 1234 & 4,28 & Sangat \\
kasi & & & Layak \\
& Visual & & & \\
Total & 3241 & 4,43 & Sangat \\
& & & Layak \\
\hline
\end{tabular}

\section{Pengaruh Penggunaan Game Edukatif} Berbasis Role-PlayingGameMaker XP terhadap Peningkatan Hasil Belajar Siswa

Pemberian pre-test dan post-test kepada siswa bertujuan untuk mengukur peningkatan hasil belajar siswa. Untuk mengukur peningkatan hasil belajar siswa, peneliti menggunakan Gain-test.

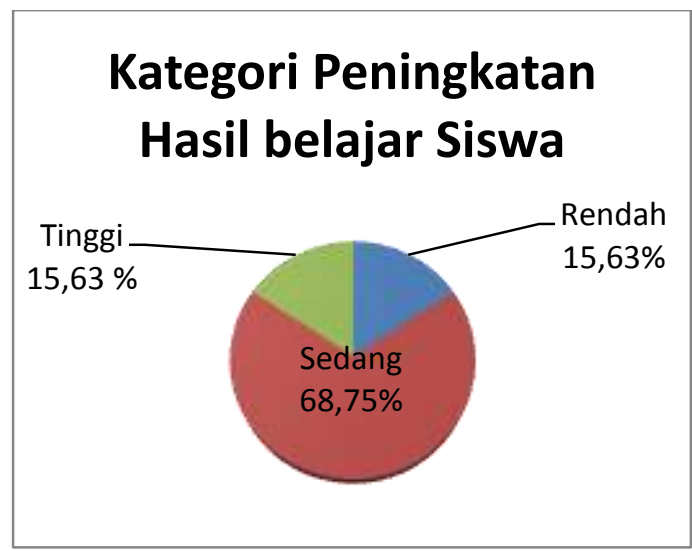

Gambar 1. Kategori Peningkatan Hasil

Belajar Siswa

\section{PEMBAHASAN}

\section{Pengembangan Game Edukatif Berbasis}

\section{RPG Maker XP}

Proses pengembangan media pembelajaran berbasis game diawali dari adanya potensi sekolah yang memiliki sarana dan prasarana yang memadai. Selain itu, anak-anak pada umumnya lebih menyukai game apalagi ketika mereka bisa belajar sambil bermain. Hal ini didukung dari hasil penilaian siswa pada saat uji coba, komentar yang diberikan lebih condong ke arah positif. Melihat adanya potensi dan masalah yang ada, peneliti kemudian menggali informasi mengenai kompetensi yang diajarkan di Kelas XI AK terutama kompetensi yang sekiranya diajarkan pada saat game diujicobakan. Selain informasi mengenai kompetensi, peneliti juga mencari informasi terkait dengan pembuatan game itu sendiri. Informasi tersebut antara lain hardware 
dan software yang dibutuhkan dan cara atau langkah-langkah pembuatan game. Untuk itu peneliti mencari tutorial pembuatan game dengan RPG Maker XP dengan cara download pada website SEAMOLEC. SEAMOLEC merupakan lembaga pusat pendidikan jarak jauh yang mencetuskan penggunaan aplikasi RPG Maker XP sebagai game yang memuat materi yang bisa digunakan sebagai media pembelajaran yang dapat digunakan di sekolah maupun digunakan secara individu oleh siswa. Peneliti kemudian belajar dan mengalami proses trial and error dalam pembuatan game ini.

Peneliti kemudian membuat desain atau rancangan game mulai dari tampilannya sampai dengan materi yang akan disampaikan beserta soal-soalnya. Berdasarkan desain yang telah dibuat, kemudian peneliti mulai membuat game dimana prosesnya dimulai dari pembuatan map atau tempat yang dilalui oleh player, dilanjutkan dengan memasukkan fungsifungsi (pengkodean) agar game bisa dijalankan (dalam RPG Maker XP istilah ini disebut dengan eventing), testing untuk mengetahui apakah event tersebut berjalan atau tidak, serta terakhir yaitu memaketkan game agar game bisa dioperasikan atau dimainkan pada komputer yang tidak terinstallsoftware RPG Maker XP. Kemudian game dikemas ke dalam CD.
Langkah selanjutnya adalah validasi produk. Validasi game edukatif ini dilakukan oleh beberapa ahli yaitu: Ahli Media, Ahli Materi, dan Guru. Hasil yang diperoleh adalah game layak untuk diujicobakan dengan beberapa revisi yang diberikan oleh para ahli dan guru. Berdasarkan saran-saran yang diberikan pada saat validasi, peneliti kemudian melakukan revisi terhadap bagian-bagian yang harus direvisi pada game. Pada tahap ini dihasilkan sebuah produk game edukatif yang siap untuk diujicobakan.

Game yang sudah direvisi kemudian diujicobakan pada siswa kelas XI AK 1 pada hari Jumat, 28 Februari 2014 di Labkom Akuntansi SMK Negeri 1 Godean sebanyak 32 siswa. Uji coba diawali dengan kegiatan mengerjakan pretest untuk mengukur kemampuan awal siswa, dilanjutkan dengan mengoperasikan game, kemudian setelah selesai siswa kembali mengerjakan soal yaitu post-test dan dilanjutkan dengan mengisi angket. Langkah terakhir yang dilakukan dalam pengembangan game edukatif ini yaitu Analisis dan Revisi Produk Akhir. Berdasarkan data-data yang didapatkan pada saat uji coba, peneliti melakukan analisis apakah saran dari siswa perlu diperbaiki atau tidak. Menurut hasil analisis peneliti, saran-saran yang diberikan oleh siswa perlu diperbaiki agar 
game dapat menjadi lebih baik lagi.

Setelah proses revisi selesai, game edukatif berbasis RPG Maker XP ini sudah menjadi produk jadi dan langkah pengembangan dalam penelitian ini dihentikan pada tahap ini.

\section{Kelayakan Game Edukatif Berbasis RPG Maker XP}

Media yang telah dibuat kemudian divalidasi untuk mengetahui tingkat kelayakan media. Validasi dilakukan oleh dosen sebagai ahli media dan ahli materi, serta guru sebagai pelaksana pembelajaran di sekolah.

a. Ahli media

Hasil validasi dari ahli media menunjukkan rata-rata penilaian oleh ahli media diperoleh nilai 4,26 yang termasuk ke dalam kategori Sangat Layak. Dengan demikian game edukatif berbasis RPG Maker XP ini layak digunakan sebagai media pembelajaran.

b. Ahli materi

Ahli materi melakukan penilaian terhadap materi pembelajaran yang disampaikan pada game. Secara keseluruhan, rata-rata penilaian oleh ahli materi diperoleh nilai 4,14 yang termasuk ke dalam kategori Layak. Dengan demikian, game edukatif berbasis RPG Maker XP ini layak digunakan sebagai media pembelajaran.

c. Guru

Secara keseluruhan, rata-rata penilaian oleh guru diperoleh nilai 4,77 yang termasuk ke dalam kategori Sangat Layak. Dengan demikian, game edukatif berbasis RPG Maker XP ini layak digunakan sebagai media pembelajaran.

d. Siswa

Secara keseluruhan, rata-rata penilaian oleh siswa diperoleh nilai 4,43 yang termasuk ke dalam kategori Sangat Layak. Dengan demikian game edukatif berbasis RPG Maker XP ini layak digunakan sebagai media pembelajaran.

Penilaian kelayakan game edukatif berbasis RPG Maker XP berdasarkan ahli media termasuk pada kategori Sangat Layak, ahli materi termasuk kategori Layak, Guru termasuk kategori Sangat Layak, dan siswa termasuk kategori Sangat Layak. Berdasarkan penilaian dari ahli media, ahli materi, guru, dan siswa dapat disimpulkan bahwa Game edukatif Berbasis Role Playing Game (RPG) Maker XP layak digunakan sebagai Media Pembelajaran Akuntansi Siswa SMK Kelas XI. 


\section{Pengaruh Penggunaan Game Edukatif}

Berbasis Role-Playing Game Maker XP terhadap Peningkatan Hasil Belajar Siswa

Peningkatan hasil belajar siswa diukur berdasarkan nilai pre-test dan posttest yang diberikan pada saat uji coba lapangan. Analisis peningkatan hasil belajar siswa menggunakan Analisis Gain. Hasil analisis menunjukkan bahwa skor gain yang diperoleh adalah 0,55. Skor tersebut termasuk dalam kategori sedang. Berdasarkan hasil tersebut dapat disimpulkan bahwa penggunaan game edukatif berbasis RPG Maker XP dapat meningkatkan hasil belajar siswa dan peningkatan tersebut masuk dalam kategori Sedang.

\section{SIMPULAN DAN SARAN}

\section{Simpulan}

Berdasarkan hasil penelitian dan pembahasan, dapat disimpulkan:

a. Pengembangan game edukatif berbasis RPG Maker XP melewati delapan tahap pengembangan yaitu identifikasi potensi dan masalah, pengumpulan informasi, desain produk, pengembangan produk, validasi desain, revisi desain, uji coba produk, analisis dan revisi produk akhir.

b. Tingkat kelayakan game edukatif ditinjau berdasarkan pendapat dari ahli media, ahli materi, guru, dan siswa. Penilaian kelayakan oleh ahli media diperoleh nilai rata-rata 4,26 dengan kategori Sangat Layak, ahli materi diperoleh nilai rata-rata 4,14 dengan kategori Layak, guru diperoleh nilai 4,77 dengan kategori Sangat Layak, dan siswa diperoleh nilai 4,43 dengan kategori Sangat Layak. Dengan demikian, game edukatif berbasis RPG Maker XP ini layak digunakan sebagai media pembelajaran akuntansi SMK Kelas XI.

c. Pengaruh penggunaan game edukatif berbasis RPG Maker XP terhadap hasil belajar siswa diukur dengan cara memberikan pre-test sebelum uji coba dan post-test setelah uji coba. Hasil pre-test dan post-test dianalisis peningkatannya dengan menggunakan Gain-test. Rata-rata nilai pre-test siswa yaitu 3,26 dan rata-rata nilai post-test siswa yaitu 6,95. Berdasarkan nilai rata-rata tersebut, kemudian dihitung nilai gain dan diperoleh nilai gain sebesar 0,55. Nilai gain tersebut masuk dalam kategori peningkatan "Sedang". Dengan demikian penggunaaan game edukatif Berbasis RPG Maker XP dapat meningkatkan hasil belajar siswa. 


\section{Saran}

Berdasarkan penelitian, Game

Edukatif Berbasis RPG Maker XP ini masih memiliki banyak kekurangan. Oleh karena itu, terdapat beberapa saran yang dapat digunakan sebagai masukan, saran tersebut antara lain:

a. Perlu adanya pengembangan lebih lanjut mengenai game ini dengan materi yang lain yang lebih lengkap.

b. Pengembangan game menyesuaikan waktu pembelajaran di kelas, sehingga siswa bisa memainkan game sampai selesai agar semua materi yang ada pada media dapat disampaikan semua.

c. Perlu penambahan penjelasan yang lebih rinci mengenai cara bermain game genre Role-Playing Game.

d. Soal yang akan dicantumkan dalam media seharusnya divalidasi oleh ahli terlebih dahulu sehingga dapat diketahui validitas soal tersebut.

\section{DAFTAR PUSTAKA}

Agate. (2012). Hasil Survey Gamer Indonesia-Februari 2012, diakses dari http://agatestudio.com/blog/2012/0 2/hasil-survey-gamer-indonesiafebruari-2012/\#more-681, pada 9 Oktober 2013.

Dina Indriana. (2011). Ragam Alat Bantu Media Pengajaran. Yogyakarta: Diva Press.

Hake, Richard. (2012). Analyzing Change/Gain Scores. Diakses dari http://www.physics.indiana.edu/ S di/AnalyzingChange-Gain.pdf, pada tanggal 25 Januari 2014.

Samuel Henry. (2010). Cerdas dengan Game. Jakarta: PT Gramedia Pustaka Utama.

SEAMOLEC. (2010). Tutorial Pembuatan Game dengan RPG Maker XP. Jakarta: SEAMOLEC.

Sugiyono. (2012). Metode Penelitian Kualitatif, Kuantitatif, dan $R \& D$. Bandung: Penerbit Alfabeta.

Wina Sanjaya. (2012). Perencanaan dan Desain Sistem Pembalajaran. Jakarta: Kencana.

(2012). Strategi Pembelajaran Berorientasi Standar Pendidikan. Jakarta: Kencana. 